\title{
On the use of diatom-based biological monitoring Part 1: A comparison of the response of diversity and aut-ecological diatom indices to water quality variables in the Marico-Molopo River catchment
}

\author{
PA de la Rey ${ }^{1 *}$, L van Rensburg ${ }^{1}$ and $A$ Vosloo ${ }^{2}$ \\ ${ }^{1}$ School for Environmental Science and Development, North-West University, Potchefstroom, South Africa \\ ${ }^{2}$ School of Biological and Conservation Science, University of KwaZulu-Natal, Durban, South Africa
}

\begin{abstract}
Two main approaches have been followed in using diatoms as bio-indicators in the past few decades namely species diversity indices and aut-ecological indices. This study, based on 102 water quality and epilithic diatom samples from the Crocodile Groot-Marico catchment in South Africa, evaluated both types of indices by establishing how well they reflect changes in water quality. It was found that less of the variation in diversity indices could be attributed to changes in water quality variables than was the case for the aut-ecological indices. Furthermore it was found that species diversity indices tend to be higher at intermediate levels of pollution, rather than at low levels of pollution.
\end{abstract}

Keywords: diatoms; Bacillariophyceae; bioindicators; species diversity indices; water quality; aut-ecological indices

\section{Introduction}

Southern Africa is a subcontinent notorious for its unpredictable rainfall. South Africa is a semi-arid country, and the decline in the quality of available water is one of the biggest problems currently facing the country (Davies and Day, 1998). For this reason the integrated management of water resources has enjoyed high priority in the National Water Act as well as in research and management actions by both government and non-government organisations.

Walmsley et al. (2000) state that indicators are an ideal means by which progress towards integrated water resource management can be monitored, in that they provide a summary of conditions, rather like temperature and blood pressure are used to measure human health. Using the same analogy, it is important to be able to distinguish between indicators which can truly be linked to health and are not just features of the system which do not have relevance to the question posed. For the aforementioned reason it is important to be able to test indicators quantitatively in order to assess how closely they can be linked to the health of aquatic ecosystems, in the case of water resource management, and/or water quality. Diatoms have been shown to have narrow tolerance ranges for many environmental variables and respond rapidly to environmental change, making them ideal indicators (Reid et al., 1995).

Several kinds of indicators have been proposed over the years to evaluate ecosystem health. Two main groups of indicators using diatom community data will be discussed in this paper namely diversity indices and aut-ecological indices.

* To whom all correspondence should be addressed.

Alternative address: Africa Geo-Environmental Services,

PO Box 19460, Potchefstroom 2522, South Africa

푬 +27 18297 6588; fax: +27 18297 4813;

e-mail: adelarey@ages-group.com

Received 30 October 2006; accepted in revised form 28 November 2007.

\section{Species diversity/species richness indicators}

Ecosystem stability can be defined as the ability of a system to recover to an equilibrium state after disturbance, or simply the persistence of the system (May, 1976). The diversity-stability hypothesis asserts that species vary in their traits and that in a highly diverse (species rich) system, there will be some species than can compensate for the loss of others should disturbance occur in such a system (Pimm, 1984; Elton, 1958). Thus, species rich systems are more likely to be considered stable. Another common view is that this theory predicts a decrease of diversity as pollution increases. The pollution intolerant species decline in abundance and the pollution tolerant species can grow rapidly without competition for space, nutrients, or other resources. This results in community abundance patterns of heavy dominance and fewer species (Van Dam, 1982).

It is on the basis of the two abovementioned hypotheses that species diversity indices enjoy widespread use in ecology and, more specifically, aquatic ecology. Diversity indices are related to community structure and are not specific to any type of contamination. Species diversity indices consist mainly of three measures namely: species richness (related to the number of species), the evenness (how evenly the individuals are distributed between the species) and a combined measure called the diversity index such as the Shannon Diversity Index (Shannon and Weaver, 1949).

Species diversity indices based on benthic diatom assemblages are regularly used in the study of water resources. In such instances these indices are mainly used to determine the impact of certain actions and pollutants on aquatic systems (Cunningham et al., 2003; Gómez 1999; Gracia-Criado et al., 1999). An alternative to species diversity/species richness indicators are aut-ecological indices.

\section{Aut-ecological Indices}

Aut-ecological indices use the relative abundance of species 
in assemblages, their ecological preferences, sensitivities, or tolerances to infer environmental conditions in an ecosystem (Stoermer and Smol, 1999). Put in another way, aut-ecological indices make use of the niche requirements and habitat preferences of the individual species or higher taxonomic groupings. In such indices long-term data gathered about the tolerances of a species are used to compile an index which can, in turn, be used to deduce environmental conditions from the species composition by taking into account the specific tolerances of the species in the community surveyed. These indices can be constructed to measure specific pollutants or general environmental conditions. A number of diatom-based aut-ecological indices are based on the weighted average equation of Zelinka and Marvan (1961) and have the basic form:

$$
\text { index }=\frac{\sum_{j-1}^{n} a_{j} s_{j} v_{j}}{\sum_{j=1}^{n} a_{j} v_{j}}
$$

where:

$$
\begin{aligned}
& a_{j}=\text { abundance (proportion) of species } j \text { in sample } \\
& v_{j}=\text { indicator value } \\
& s_{j}=\text { pollution sensitivity of species } j
\end{aligned}
$$

The method mainly utilises the distribution of species along a water quality gradient in terms of sensitivity to pollution as well as broadness of the species distribution along the water quality gradient. This equation is used in many diatom-based indices including the Descy's Index or DES (Descy, 1979), the Generic Diatom Index or GDI (Coste and Ayphassorho, 1991), the Specific Pollution sensitivity Index or SPI (Coste in Cemagref, 1982), the Biological Diatom Index or BDI (Lenoir and Coste, 1996), the Artois-Picardie Diatom Index or APDI (Prygiel et al., 1996), Sládeček's index or SLA (Sládeček, 1986), the Eutrophication/ Pollution Index or EPI (Dell'Uomo, 1996), Rott's Index or ROT (Rott, 1991), Leclercq and Maquet's Index or LMI (Leclercq and Maquet, 1987), etc. Such indices mainly vary in terms of species included in the calculation and the tolerances assigned to such species.

Diatom indices constructed by this approach have been tested with success in South Africa (Taylor et al., 2007; De la Rey et al., 2004) and in many countries in Europe and the rest of the world (Sabater, 2000; Kelly, 1998; Reavie et al., 1995; Zeeb et al., 1994; Hall and Smol, 1992).

\section{Rationale}

This research paper consists of two parts. This paper (Part 1) tests the performance of two approaches to the use of diatoms as bio-indicators namely diversity indices and aut-ecological indices. The second part of this paper (Part 2) (De la Rey, 2008) compares the performance of diatom-based indices with that of a macro-invertebrate index (SASS 5) in terms their ability to indicate changes in water quality variables.

The purpose of Part 1 is to compare diversity indices and aut-ecological indices as measures of aquatic ecosystem health by comparing their response to water quality variables. This will enable an informed decision as to which of the two approaches will be most appropriate when using diatoms as bio-indicators in river and stream ecosystems in South Africa.

Since water quality is one of the main environmental factors affecting the ecology in rivers and streams, it can be used as a measure of the applicability of indicators for integrated water resource management. Diatoms are appropriate for the purpose of this study as they provide interpretable indications of specific changes in water quality (McCormack and Cairns, 1994).

\section{Materials and methods}

\section{Sampling localities}

Thirty three sites were identified in the Groot Marico and Molopo River systems for the study (Fig. 1). The identified sites form part of the River Health Program of the North West Province, South Africa. Samples were collected in April, June, September and November 2005 at the sites, as water levels permitted (at times certain samples could not be collected due to low water levels), resulting in a total of 102 separate data points with diatom data and same-day water quality data. These sites were chosen to represent a wide range of water quality (see water quality summary in Table 1) as well as the wide range of diatom index scores recorded (SPI: 1.3-19.7 out of a possible 20).

The Marico River originates south of Groot Marico town and feeds into the Limpopo River in the north. The origin of the Marico River falls within the Groot Marico dolomitic aquifer compartment. The two primary sources of this river are the Grootfontein dolomitic eye, that gives rise to Kaaloog-se-loop and an eye on the farm Renosterhoek 343JP that feeds the Rietspruit. Secondary sources include Draaifontein tributary that is of a mixed dolomitic nature and the Sterkstroom tributary that is fed by springs of a non-dolomitic nature. Other tributaries of the Marico River include the Klein Marico River. This tributary is seasonal and is thus not a major flow contributor to the Marico River. The 'Molemane-se-Loop' is of a dolomitic nature originating in the Molemane Nature Reserve. Major dams in this sub-catchment include the Marico-Bosveld Dam in the upper catchment and the Molatedi Dam further downstream. The upper reaches of this sub-catchment are not densely populated (RHP, 2005).

The Molopo River originates east of Mafikeng and feeds into the Vaal River in the south west. The origin of the Molopo River falls within the Groot Marico dolomitic aquifer compartment. The primary source of this river is the Molopo dolomitic eye. Major dams in this sub-catchment include Cooke's Lake, Montshioa Dam, Lotlamoreng, Modimolo Dam (Setumo) and the main dam in the system is the Disaneng Dam close to the Botswana Border.

TABLE 1

Descriptive statistics of water quality variables

\begin{tabular}{|l|l|l|l|l|l|}
\hline & Mean & Median & Min & Max & $\begin{array}{l}\text { Standard } \\
\text { deviation }\end{array}$ \\
\hline $\mathrm{Ca}(\mathrm{mg} / \ell)$ & 32.18 & 30.06 & 1.49 & 82.25 & 23.78 \\
\hline $\mathrm{Cl}(\mathrm{mg} / \ell)$ & 14.98 & 4.99 & 2.00 & 145.57 & 24.12 \\
\hline $\mathrm{F}(\mathrm{mg} / \ell)$ & 0.18 & 0.15 & 0.05 & 0.61 & 0.14 \\
\hline $\mathrm{K}(\mathrm{mg} / \ell)$ & 2.17 & 0.73 & 0.15 & 11.28 & 2.91 \\
\hline $\mathrm{Mg}(\mathrm{mg} / \ell)$ & 24.27 & 18.52 & 1.02 & 65.79 & 18.52 \\
\hline $\mathrm{NH}_{4}(\mathrm{mg} / \ell)$ & 0.68 & 0.02 & 0.02 & 16.78 & 2.43 \\
\hline $\mathrm{NO}_{3}+\mathrm{NO}_{2}$ & 0.38 & 0.09 & 0.04 & 7.52 & 1.02 \\
\hline $\mathrm{Na}^{(\mathrm{mg} / \ell)}$ & 11.91 & 3.45 & 1.00 & 109.31 & 18.05 \\
\hline $\mathrm{PO}_{4}(\mathrm{mg} / \ell)$ & 0.21 & 0.02 & 0.01 & 4.90 & 0.70 \\
\hline $\mathrm{SO}(\mathrm{mg} / \ell)$ & 15.18 & 5.70 & 2.00 & 113.27 & 20.22 \\
\hline $\mathrm{Si}(\mathrm{mg} / \ell)$ & 6.26 & 5.94 & 1.27 & 11.20 & 2.16 \\
\hline $\mathrm{pH}$ & 8.16 & 8.23 & 7.31 & 8.66 & 0.30 \\
\hline $\mathrm{DO}(\mathrm{mg} / \ell)$ & 6.55 & 6.94 & 1.81 & 11.48 & 2.49 \\
\hline $\mathrm{Temperature}\left({ }^{\circ} \mathrm{C}\right)$ & 17.98 & 18.60 & 7.70 & 29.52 & 4.18 \\
\hline Turbidity $(\mathrm{NTU})$ & 12.49 & 6.77 & 0.00 & 75.10 & 14.34 \\
\hline EC $(\mathrm{mS} / \mathrm{m})$ & 39.21 & 31.10 & 2.66 & 113.70 & 28.57 \\
\hline $\mathrm{TAL}(\mathrm{mg} / \ell)$ & 168.73 & 146.83 & 4.00 & 497.00 & 121.00 \\
\hline
\end{tabular}




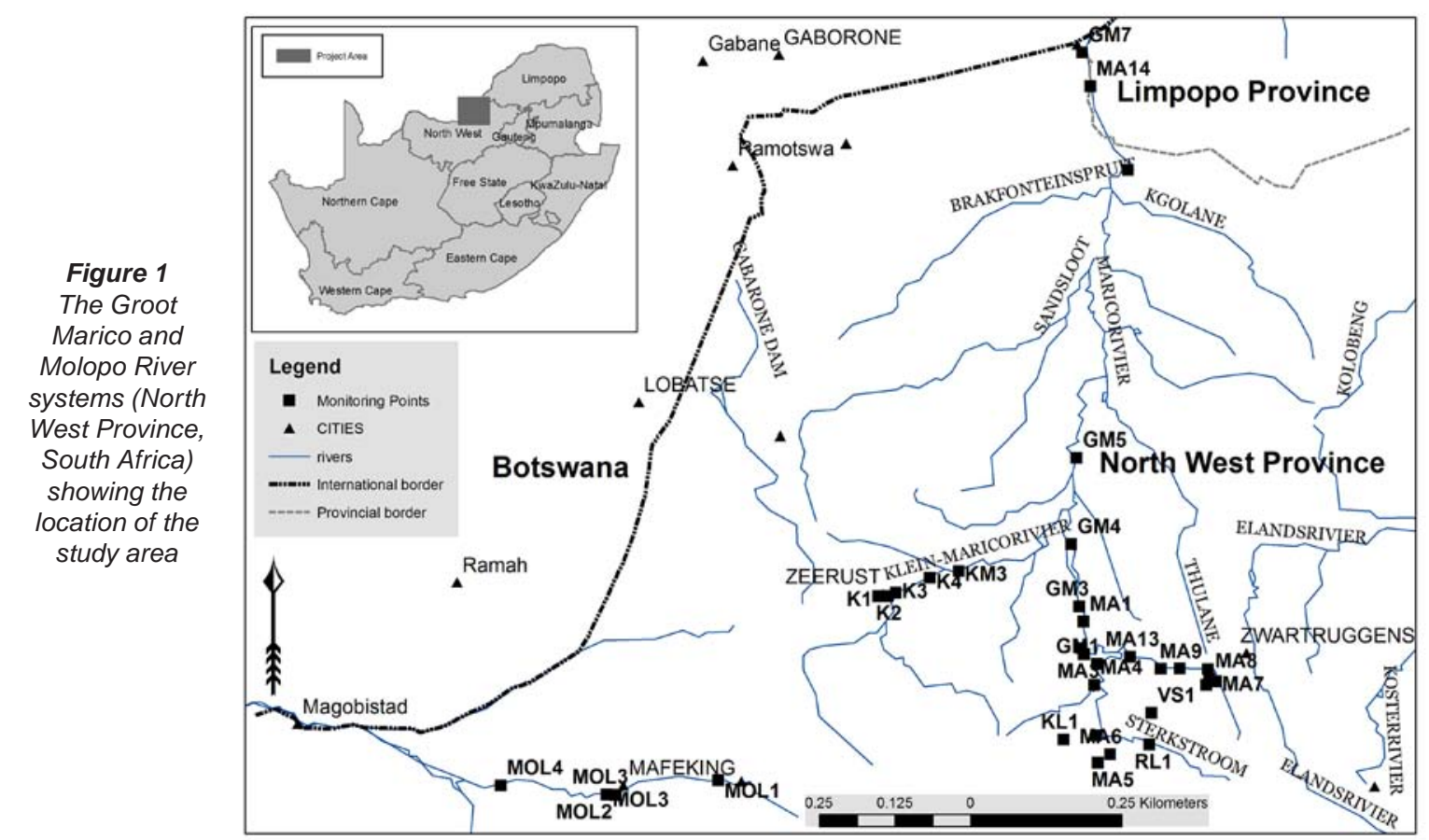

From the results in the study, it is clear that the water quality deteriorates downstream, especially as it flows through the towns of Groot Marico, Zeerust and Mafikeng. Downstream water quality impacts may also occur from impoundments (dams and weirs) as well as from agricultural activities.

\section{Indices}

Diatoms were collected, prepared and enumerated according to the protocol as set out in Taylor et al. (2005). Only epilithic diatoms were sampled for the study due to the fact that this is the community of preference for the most diatom indices as well as being the community that yields the best coefficients when multiple regressions are performed with water quality variables (Hodgkiss and Law, 1985). Diatom identification was carried out according to the nomenclature of Krammer and Lange Bertalot (1986-1991) and the SPI, BDI, SPI was chosen as it has the broadest species base; BDI showed the best overall correlation to water quality variables in studies performed recently on the Vaal River (Taylor et al., 2007).

Species diversity index, species evenness and number of species were calculated using the OMNIDIA software package (Lecointe et al., 1993). For the biodiversity indicator (species diversity, species evenness and number of species) calculations, the same numbers of cells counted for the aut-ecological index calculation were used (400 cells per slide). It is a well-known fact that there is a relationship between diversity indices and sample size (Seber, 1986; Lewins and Joanes, 1984). Since the same numbers of cells were counted on each slide, the data are comparable between samples as well as between indices.

\section{Water quality}

Instream water quality measurements for $\mathrm{pH}$, dissolved oxygen $(\mathrm{mg} / \ell)$, electrical conductivity $(\mathrm{mS} / \mathrm{m})$ as well as temperature $\left({ }^{\circ} \mathrm{C}\right)$ were done at each locality by means of an YSI 556 MPS Multimeter. Water samples were taken concomitantly with biological samples at every site.

The water sample was preserved by means of an $\mathrm{HgCl}_{2}$ ampoule broken into each sample and delivered to Resource Quality Services (Department of Water Affairs and Forestry, Roodeplaat) for analysis. The following water quality variables formed part of the analysis:

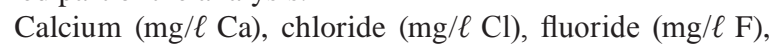
potassium $(\mathrm{mg} / \ell \mathrm{K})$, magnesium $(\mathrm{mg} / \ell \mathrm{Mg}$ ), ammonia $\left(\mathrm{mg} / \ell \mathrm{NH}_{4}-\mathrm{N}\right)$, nitrate and nitrite $\left(\mathrm{mg} / \ell \mathrm{NO}_{3}+\mathrm{NO}_{2}\right)$, sodium $(\mathrm{mg} / \ell \mathrm{Na})$, ortho-phosphate $\left(\mathrm{mg} / \ell \mathrm{PO}_{4}-\mathrm{P}\right)$, sulphate $(\mathrm{mg} / \ell$

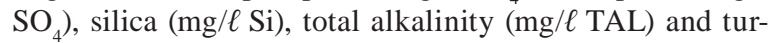
bidity (NTU, nephelometric turbidity units).

\section{Statistical analysis}

Multiple regressions and correlation analysis were performed using the STATISTICA software package (Release 7, Stat Soft. Inc., United States of America), while principle component analysis (PCA) was performed using CANOCO for Windows (Version 4.51, Biometris-Plant Research International, The Netherlands). Before analysis, all the data were standardised by subtracting the sample mean and dividing the result by the sample standard deviation (Hair et al., 1998). This was done to ensure that all the variables could contribute equally to the regressions and correlations by removing the scale factor. For the regressions the forward stepwise method was chosen to eliminate variables that do not contribute to the regression. For the purpose of the multiple regressions the Electrical Conductivity and Total Alkalinity were left out of the analysis as these variables contributed to multi-colinearity in the data, due to high correlation with other water quality variables (e.g. $\mathrm{Ca}, \mathrm{Cl}, \mathrm{F}, \mathrm{K}, \mathrm{Mg}, \mathrm{Na}, \mathrm{SO}_{4}$ ). The $\mathrm{R}^{2}$ value was used, instead of the $\mathrm{R}$ value, as it is a stricter measure of the predictability of multiple regression.

\section{Results}

\section{Diversity indices}

Table 2 represents the results for the multiple regression analysis for water quality and diatom species diversity. The $\mathrm{R}^{2}$ for the regression was 0.215 . This shows that approximately $21.5 \%$ of 
the variation in the diatom species diversity could be attributed to the measured water quality variables. The beta values in the table are the regression coefficients while the p-values indicate whether a specific variable contributed statistically significant to the regression. Water quality variables that contributed significantly $(\mathrm{p}<0.05)$ to the regression were fluoride and the $\mathrm{pH}$ of the water. The fact that changes in fluoride and $\mathrm{pH}$ concentrations influence diatom community structures have been noted by several authors (Joy and Balakrishnan, 1990; Ares et al., 1983; Lewin, 1962).

\begin{tabular}{|l|c|c|c|}
\hline \multicolumn{4}{|c|}{$\begin{array}{c}\text { TABLE 2 } \\
\text { Regression summary for Shannon species } \\
\text { diversity with water quality (italicised values } \\
\text { significant at } \mathbf{p}<\mathbf{0 . 0 5})\end{array}$} \\
\hline \multirow{2}{*}{$\mathbf{N}=\mathbf{1 0 2}$} & \multicolumn{3}{|c|}{$\mathbf{R}^{\mathbf{2}=\mathbf{0 . 2 1 5}}$} \\
\cline { 2 - 4 } & Beta & Std. err. of Beta & p-level \\
\hline Intercept & & & $<\mathbf{0 . 0 0 1}$ \\
\hline $\mathrm{F}(\mathrm{mg} / \ell)$ & $\mathbf{0 . 3 8 5}$ & $\mathbf{0 . 1 3 1}$ & $\mathbf{0 . 0 0 4}$ \\
\hline $\mathrm{pH}$ & $\mathbf{- 0 . 3 4 7}$ & $\mathbf{0 . 1 0 9}$ & $\mathbf{0 . 0 0 2}$ \\
\hline $\mathrm{SO}_{4}(\mathrm{mg} / \ell)$ & 0.175 & 0.125 & 0.164 \\
\hline $\mathrm{DO}(\mathrm{mg} / \ell)$ & 0.101 & 0.100 & 0.313 \\
\hline
\end{tabular}

The results for the regression performed to explain species evenness with water quality are provided in Table 3 . The $\mathrm{R}^{2}$ value for prediction significance of water quality for this variable was only slightly lower than for the species diversity at $20 \%$. Once again the significant contributors to the regression were $\mathrm{pH}$ and fluoride.

\begin{tabular}{|l|c|c|c|}
\hline \multicolumn{4}{|c|}{$\begin{array}{c}\text { TABLE } \mathbf{3} \\
\text { Regression summary for Pielou species } \\
\text { evenness with water quality (italicised values } \\
\text { significant at } \mathbf{p}<\mathbf{0 . 0 5})\end{array}$} \\
\hline \multirow{3}{*}{$\mathbf{N = 1 0 2}$} & \multicolumn{3}{|c|}{$\mathbf{R}^{\mathbf{2}=\mathbf{0 . 2 0 1}}$} \\
\cline { 2 - 4 } & Beta & Std. err. of Beta & p-level \\
\hline Intercept & & & $<\mathbf{0 . 0 0 1}$ \\
\hline $\mathrm{F}(\mathrm{mg} / \ell)$ & $\mathbf{0 . 4 3 0}$ & $\mathbf{0 . 1 0 4}$ & $<\mathbf{0 . 0 0 1}$ \\
\hline $\mathrm{pH}$ & $\mathbf{- 0 . 2 1 1}$ & $\mathbf{0 . 1 0 5}$ & $\mathbf{0 . 0 4 8}$ \\
\hline $\mathrm{PO}_{4}(\mathrm{mg} / \ell)$ & 0.183 & 0.093 & 0.051 \\
\hline
\end{tabular}

The regression performed for the number of diatom species and water quality (Table 4) indicates that considerably more of the variation in the values of this index can be explained by the measured water quality variables. Just over $32 \%$ of the variation in the number of species encountered in samples could be attributed to water quality variables and $\mathrm{Ca}, \mathrm{Mg}, \mathrm{Si}$, and $\mathrm{K}$ were the significant contributors in the regression model.

Archibald (1971) stated, in his studies on South African diatom species diversity, that clean water samples displayed diatom diversity scores between that of moderately enriched and polluted samples. This result was supported by findings of Van Dam (1982) by demonstrating that the highest number of diatom species occurred in moorland pools which were moderately affected by acidification as opposed to the low diversity found in very acidic pools. That diversity tends to be high at 'medium water quality' and lower at either 'good' or 'poor' water quality suggests a quadratic relationship of species diversity to disturbance may be more appropriate than a linear one. To test whether this tendency is also followed in the current data set, a quadratic or $2^{\text {nd }}$ degree polynomial regression was fitted on the data. This

\begin{tabular}{|c|c|c|c|}
\hline \multicolumn{4}{|c|}{$\begin{array}{c}\text { TABLE } 4 \\
\text { Regression summary for the number of diatom } \\
\text { species with water quality (italicised values } \\
\text { significant at } p<0.05 \text { ) }\end{array}$} \\
\hline \multirow[t]{2}{*}{$\mathrm{N}=102$} & \multicolumn{3}{|c|}{$R^{2}=0.321$} \\
\hline & Beta & Std. err. of Beta & p-level \\
\hline Intercept & & & $<0.001$ \\
\hline $\mathrm{pH}$ & -0.239 & 0.123 & 0.056 \\
\hline $\mathrm{F}(\mathrm{mg} / \ell)$ & 0.151 & 0.219 & 0.494 \\
\hline $\mathrm{Na}(\mathrm{mg} / \mathrm{\ell})$ & -1.462 & 0.845 & 0.087 \\
\hline Temperature $\left({ }^{\circ} \mathrm{C}\right)$ & -0.090 & 0.102 & 0.379 \\
\hline $\mathrm{Ca}(\mathrm{mg} / \mathrm{\ell})$ & -1.072 & 0.270 & $<0.001$ \\
\hline $\mathrm{Mg}(\mathrm{mg} / \ell)$ & 0.802 & 0.310 & 0.011 \\
\hline $\mathrm{Si}(\mathrm{mg} / \ell)$ & 0.319 & 0.149 & 0.036 \\
\hline $\mathrm{SO}_{4}(\mathrm{mg} / \ell)$ & 0.251 & 0.174 & 0.153 \\
\hline $\mathrm{K}(\mathrm{mg} / \ell)$ & 0.592 & 0.287 & 0.042 \\
\hline Turbidity (NTU) & -0.198 & 0.115 & 0.089 \\
\hline $\mathrm{Cl}(\mathrm{mg} / \mathrm{\ell})$ & 0.740 & 0.735 & 0.317 \\
\hline
\end{tabular}

was done by the use of, for example Ca as well as (Ca) ${ }^{2}$ (a quadratic term), as terms in the regression with species diversity indices (see e.g. Hair et al., 1998 or Neter et al., 1985). If the results are better than those for the linear regression it would show that the relationship is therefore rather quadratic than linear. This observation would indicate that the use of diatom species diversity in a strictly linear fashion as tool to evaluate water quality is not optimal.

Tables 5, 6 and 7 present the $2^{\text {nd }}$ degree polynomial regressions that were performed, for species diversity, species evenness and number of species, respectively, with water quality.

As can be seen from the $\mathrm{R}^{2}$ values for the regression, which includes $2^{\text {nd }}$ degree polynomial terms of water quality variables, much more of the variation in the diversity data was explained than with the linear regressions. The $\mathrm{R}^{2}$ for species diversity increased from $21.5 \%$ to $54.5 \%$ and the $\mathrm{R}^{2}$ for the species evenness increased from $20 \%$ to $40 \%$ when including the $2^{\text {nd }}$ degree polynomial terms. The number of species showed the least amount of improvement in the $\mathrm{R}^{2}$ that increased from $32 \%$ to $43 \%$.

\section{Aut-ecological/biotic indices}

The regression summary for the biotic indices BDI and SPI is presented in Table 8 and Table 9. For both these indices water quality contributed to about $80 \%$ of the variation in the data. For the SPI the significant contributors were $\mathrm{Na}, \mathrm{Si}, \mathrm{pH}$, $\mathrm{PO}_{4}, \mathrm{Ca}, \mathrm{Cl}$ and $\mathrm{SO}_{4}$. The significant water quality contributors to the BDI were much the same as for the SPI with the addition of $\mathrm{NO}_{3}+\mathrm{NO}_{2}, \mathrm{Mg}$ and $\mathrm{F}$. When $2^{\text {nd }}$ degree polynomial regressions were fitted to the BDI and SPI, the $\mathrm{R}^{2}$ value for the regressions changed marginally from near $80 \%$ to $84 \%$ (not shown). The increase in the $\mathrm{R}^{2}$ value is probably due to a minor degree of "overfitting" due to the addition of variables to the model in the case of the $2^{\text {nd }}$ degree polynomial regression (Hair et al., 1998). This change in $\mathrm{R}^{2}$ value is small when compared to the changes encountered in the diversity related regressions (see above).

As indices are usually applied in a linear fashion (high value indicating good environmental condition, low values indicating poor environmental conditions), a linear response of index scores to water quality variables is a desirable attribute 


\begin{tabular}{|c|c|c|c|}
\hline \multicolumn{4}{|c|}{$\begin{array}{c}\text { TABLE 5 } \\
\begin{array}{c}\text { Polynominal regression summary for Shannon } \\
\text { species diversity with water quality } \\
\text { (italicised values significant at } p<0.05)\end{array} \\
\end{array}$} \\
\hline \multirow[t]{2}{*}{$\mathrm{N}=102$} & \multicolumn{3}{|c|}{$R^{2}=0.546$} \\
\hline & Beta & $\begin{array}{c}\text { Std. err. of } \\
\text { Beta }\end{array}$ & p-level \\
\hline Intercept & & & $<0.001$ \\
\hline $\mathrm{F} * \mathrm{~F}(\mathrm{mg} / \ell)$ & 0.658 & 0.167 & $<0.001$ \\
\hline $\mathrm{Ca} * \mathrm{Ca}(\mathrm{mg} / \ell)$ & 0.375 & 0.255 & 0.146 \\
\hline Temperature $\left({ }^{\circ} \mathrm{C}\right)$ & 0.223 & 0.101 & 0.030 \\
\hline $\mathrm{Ca}(\mathrm{mg} / \mathrm{l})$ & -0.947 & 0.377 & 0.014 \\
\hline $\mathrm{F}(\mathrm{mg} / \ell)$ & -0.253 & 0.229 & 0.273 \\
\hline $\mathrm{Si}(\mathrm{mg} / \ell)$ & 0.103 & 0.166 & 0.537 \\
\hline $\mathrm{DO} * \mathrm{DO}(\mathrm{mg} / \ell)$ & 0.007 & 0.097 & 0.945 \\
\hline $\mathrm{PO}_{4}(\mathrm{mg} / \ell)$ & 0.720 & 0.552 & 0.196 \\
\hline $\mathrm{K} * \mathrm{~K}(\mathrm{mg} / \mathrm{\ell})$ & -1.773 & 0.447 & $<0.001$ \\
\hline $\mathrm{Mg}(\mathrm{mg} / \ell)$ & 0.255 & 0.532 & 0.633 \\
\hline $\mathrm{Mg} * \mathrm{Mg}(\mathrm{mg} / \ell)$ & -0.378 & 0.265 & 0.158 \\
\hline $\mathrm{SO}_{4} * \mathrm{SO}_{4}(\mathrm{mg} / \ell)$ & -1.075 & 0.290 & $<0.001$ \\
\hline $\mathrm{SO}_{4}(\mathrm{mg} / \ell)$ & 1.648 & 0.499 & 0.001 \\
\hline Turbidity*Turbidity (NTU) & 0.670 & 0.219 & 0.003 \\
\hline Turbidity (NTU) & -0.601 & 0.193 & 0.003 \\
\hline $\mathrm{DO}(\mathrm{mg} / \ell)$ & 0.210 & 0.119 & 0.080 \\
\hline $\mathrm{K}(\mathrm{mg} / \ell)$ & 0.916 & 0.388 & 0.021 \\
\hline $\mathrm{PO}_{4}^{*} \mathrm{PO}_{4}(\mathrm{mg} / \ell)$ & -0.141 & 0.524 & 0.789 \\
\hline $\mathrm{NH}_{4} * \mathrm{NH}_{4}(\mathrm{mg} / \ell)$ & 0.878 & 0.371 & 0.020 \\
\hline $\mathrm{NH}_{4}(\mathrm{mg} / \mathrm{\ell})$ & -1.014 & 0.547 & 0.068 \\
\hline $\mathrm{Cl} * \mathrm{Cl}(\mathrm{mg} / \ell)$ & 0.391 & 0.217 & 0.075 \\
\hline
\end{tabular}

\begin{tabular}{|c|c|c|c|}
\hline $\begin{array}{r}\text { Th } \\
\text { Polynomial regress } \\
\text { species evenne } \\
\text { (italicised values }\end{array}$ & $\begin{array}{l}\text { LE } 6 \\
\text { n summ } \\
\text { with we } \\
\text { gnificar }\end{array}$ & $\begin{array}{l}\text { ary for Piel } \\
\text { ter quality } \\
\text { t at } p<0.05 \text { ) }\end{array}$ & \\
\hline $\mathrm{N}=102$ & & $R^{2}=0.404$ & \\
\hline & Beta & $\begin{array}{c}\text { Std. err. of } \\
\text { Beta }\end{array}$ & p-level \\
\hline Intercept & & & $<0.001$ \\
\hline $\mathrm{Si} * \mathrm{Si}(\mathrm{mg} / \ell)$ & 0.416 & 0.143 & 0.005 \\
\hline $\mathrm{Ca}^{*} \mathrm{Ca}(\mathrm{mg} / \ell)$ & 0.212 & 0.098 & 0.034 \\
\hline $\mathrm{F} * \mathrm{~F}(\mathrm{mg} / \ell)$ & 0.532 & 0.138 & $<0.001$ \\
\hline Temperature $\left({ }^{\circ} \mathrm{C}\right)$ & 0.185 & 0.087 & 0.036 \\
\hline 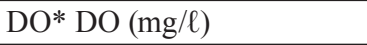 & -0.086 & 0.085 & 0.312 \\
\hline $\mathrm{PO}_{4}(\mathrm{mg} / \ell)$ & 0.771 & 0.225 & 0.001 \\
\hline $\mathrm{K} * \mathrm{~K}(\mathrm{mg} / \ell)$ & -0.737 & 0.223 & 0.001 \\
\hline Turbidity*Turbidity (NTU) & 0.257 & 0.118 & 0.032 \\
\hline $\mathrm{NH}_{4}(\mathrm{mg} / \ell)$ & -0.604 & 0.382 & 0.117 \\
\hline $\mathrm{NH}_{4} * \mathrm{NH}_{4}(\mathrm{mg} / \ell)$ & 0.298 & 0.270 & 0.272 \\
\hline
\end{tabular}

of such indices. Since the linear regressions of SPI and BDI with water quality variables are high $( \pm 80 \%)$ and little is gained from the addition of polynomial terms, it is suggested that the linear relationship of SPI and BDI with a water quality gradient is sufficient for use of the index in a linear fashion in river systems.
TABLE 7

Polynomial regression summary for the number of diatom species with water quality (italicised values significant at $p<0.05$ )

\begin{tabular}{|l|c|c|c|}
\hline \multirow{4}{*}{$\mathbf{N}=\mathbf{1 0 2}$} & \multicolumn{3}{|c|}{$\mathbf{R}^{\mathbf{2}}=\mathbf{0 . 4 3 0}$} \\
\cline { 2 - 4 } & Beta & Std. err. of Beta & p-level \\
\hline Intercept & & & $<\mathbf{0 . 0 0 1}$ \\
\hline $\mathrm{F}^{*} \mathrm{~F}(\mathrm{mg} / \ell)$ & $\mathbf{0 . 3 4 1}$ & $\mathbf{0 . 1 5 3}$ & $\mathbf{0 . 0 2 9}$ \\
\hline $\mathrm{pH}$ & -0.193 & 0.161 & 0.233 \\
\hline $\mathrm{K} * \mathrm{~K}(\mathrm{mg} / \ell)$ & -0.497 & 0.364 & 0.176 \\
\hline $\mathrm{Ca}{ }^{*} \mathrm{Ca}(\mathrm{mg} / \ell)$ & 0.710 & 0.262 & $\mathbf{0 . 0 0 8}$ \\
\hline $\mathrm{Ca}(\mathrm{mg} / \ell)$ & $\mathbf{- 1 . 7 7 8}$ & $\mathbf{0 . 3 8 6}$ & $<\mathbf{0 . 0 0 1}$ \\
\hline $\mathrm{Mg}(\mathrm{mg} / \ell)$ & $\mathbf{1 . 9 4 6}$ & $\mathbf{0 . 4 8 2}$ & $<\mathbf{0 . 0 0 1}$ \\
\hline $\mathrm{Mg}{ }^{*} \mathrm{Mg}(\mathrm{mg} / \ell)$ & $-\mathbf{0 . 6 3 8}$ & $\mathbf{0 . 2 8 1}$ & $\mathbf{0 . 0 2 6}$ \\
\hline $\mathrm{Si}{ }^{*} \mathrm{Si}(\mathrm{mg} / \ell)$ & -0.211 & 0.181 & 0.246 \\
\hline $\mathrm{Na}(\mathrm{mg} / \ell)$ & -1.153 & 0.413 & $\mathbf{0 . 0 0 6}$ \\
\hline $\mathrm{Si}(\mathrm{mg} / \ell)$ & 0.242 & 0.172 & 0.163 \\
\hline $\mathrm{PO}{ }_{4}^{*} \mathrm{PO}{ }_{4}(\mathrm{mg} / \ell)$ & 0.106 & 0.209 & 0.614 \\
\hline $\mathrm{K}(\mathrm{mg} / \ell)$ & $\mathbf{0 . 8 3 1}$ & $\mathbf{0 . 4 1 4}$ & $\mathbf{0 . 0 4 8}$ \\
\hline $\mathrm{Cl}{ }^{*} \mathrm{Cl}(\mathrm{mg} / \ell)$ & 0.492 & 0.308 & 0.115 \\
\hline $\mathrm{Temperature}\left({ }^{\circ} \mathrm{C}\right)$ & -0.148 & 0.100 & 0.142 \\
\hline $\mathrm{pH}^{*} \mathrm{pH}$ & -0.135 & 0.109 & 0.220 \\
\hline $\mathrm{DO}(\mathrm{mg} / \ell)$ & -0.113 & 0.107 & 0.295 \\
\hline
\end{tabular}

TABLE 8

Regression summary for the SPI with water quality (italicised values significant at $p<0.05$ )

\begin{tabular}{|l|c|c|c|}
\hline \multirow{2}{*}{$\mathbf{N = 1 0 2}$} & \multicolumn{3}{|c|}{$\mathbf{R}^{\mathbf{2}} \mathbf{0 . 7 9 6}$} \\
\cline { 2 - 4 } & $\mathbf{B e t a}$ & Std. err. of Beta & $\mathbf{p}$-level \\
\hline Intercept & & & 1.000 \\
\hline $\mathrm{Na}(\mathrm{mg} / \ell)$ & $\mathbf{- 1 . 9 7 8}$ & $\mathbf{0 . 5 2 4}$ & $<\mathbf{0 . 0 0 1}$ \\
\hline $\mathrm{Si}(\mathrm{mg} / \ell)$ & $\mathbf{- 0 . 2 9 7}$ & $\mathbf{0 . 0 9 3}$ & $\mathbf{0 . 0 0 2}$ \\
\hline $\mathrm{pH}$ & $\mathbf{0 . 3 0 5}$ & $\mathbf{0 . 0 6 8}$ & $<\mathbf{0 . 0 0 1}$ \\
\hline $\mathrm{NO}_{3}+\mathrm{NO}_{2}$ & 0.249 & 0.150 & 0.101 \\
\hline $\mathrm{K}_{(\mathrm{mg} / \ell)}$ & -0.231 & 0.175 & 0.191 \\
\hline $\mathrm{PO}_{4}(\mathrm{mg} / \ell)$ & $\mathbf{0 . 3 6 8}$ & $\mathbf{0 . 1 7 3}$ & $\mathbf{0 . 0 3 6}$ \\
\hline $\mathrm{NH}_{4}(\mathrm{mg} / \ell)$ & -0.054 & 0.171 & 0.752 \\
\hline $\mathrm{Ca}(\mathrm{mg} / \ell)$ & $\mathbf{- 0 . 3 4 4}$ & $\mathbf{0 . 1 7 2}$ & $\mathbf{0 . 0 4 9}$ \\
\hline $\mathrm{Cl}(\mathrm{mg} / \ell)$ & $\mathbf{1 . 1 0 8}$ & $\mathbf{0 . 4 4 9}$ & $\mathbf{0 . 0 1 5}$ \\
\hline $\mathrm{SO}(\mathrm{mg} / \ell)$ & $\mathbf{- 0 . 1 9 5}$ & $\mathbf{0 . 0 9 7}$ & $\mathbf{0 . 0 4 8}$ \\
\hline $\mathrm{F}(\mathrm{mg} / \ell)$ & 0.186 & 0.137 & 0.179 \\
\hline $\mathrm{Mg}(\mathrm{mg} / \ell)$ & 0.229 & 0.190 & 0.231 \\
\hline
\end{tabular}

\section{Principle component analysis (PCA)}

A principle component analysis was performed to visually represent the response of the two types of indicators with water quality variables. The results of this analysis are shown in Fig. 2 and Table 10. From the figure we can see that the main drivers in the water quality in the catchment are $\mathrm{Na}$ and $\mathrm{Cl}$ (correlates with the first ordination axis). The BDI and SPI indices (representing the aut-ecological indices) are strongly affected by the main drivers of the water quality in the catchment and show a strong negative response to increasing salt loadings ( $\mathrm{Na}$ and $\mathrm{Cl}$ ). The length of the vectors representing the various indices in Fig. 2 


\begin{tabular}{|c|c|c|c|}
\hline \multicolumn{4}{|c|}{$\begin{array}{c}\text { TABLE 9 } \\
\begin{array}{c}\text { Regression summary for the BDI with water quality } \\
\text { (italicised values significant at } \mathrm{p}<0.05 \text { ) }\end{array}\end{array}$} \\
\hline \multirow[t]{2}{*}{$\mathrm{N}=102$} & \multicolumn{3}{|c|}{$R^{2}=0.810$} \\
\hline & Beta & Std. err. of Beta & p-level \\
\hline Intercept & & & 1.000 \\
\hline $\mathrm{Na}(\mathrm{mg} / \ell)$ & -2.032 & 0.458 & $<0.001$ \\
\hline $\mathrm{Si}(\mathrm{mg} / \ell)$ & -0.287 & 0.080 & 0.001 \\
\hline $\mathrm{NO}_{3}+\mathrm{NO}_{2}(\mathrm{mg} / \ell)$ & 0.305 & 0.083 & $<0.001$ \\
\hline $\mathrm{K}(\mathrm{mg} / \ell)$ & -0.265 & 0.152 & 0.084 \\
\hline $\mathrm{pH}(\mathrm{mg} / \ell)$ & 0.178 & 0.064 & 0.006 \\
\hline $\mathrm{Ca}(\mathrm{mg} / \ell)$ & -0.571 & 0.152 & $<0.001$ \\
\hline $\mathrm{Cl}(\mathrm{mg} / \ell)$ & 1.159 & 0.387 & 0.004 \\
\hline $\mathrm{PO}_{4}-\mathrm{P}(\mathrm{mg} / \ell)$ & 0.305 & 0.096 & 0.002 \\
\hline $\mathrm{Mg}(\mathrm{mg} / \ell)$ & 0.360 & 0.178 & 0.046 \\
\hline $\mathrm{F}(\mathrm{mg} / \ell)$ & 0.229 & 0.113 & 0.047 \\
\hline $\mathrm{SO}_{4}(\mathrm{mg} / \ell)$ & -0.174 & 0.089 & 0.054 \\
\hline
\end{tabular}

also indicates a much stronger effect of water quality variables on the BDI and SPI than on the diversity index measures (as the vectors of the former are longer than those of the latter).

Diversity and evenness as shown in Fig. 2 seem to increase in the same direction as most of the water quality variables. This might be caused by the fact that diversity seems to be higher at sites with intermediate values for the water quality parameters measured in the study.

The number of species (Fig. 2) was associated with increased oxygen in the water and negatively associated with the chemical variables that denote possible organic loading of the water system $\left(\mathrm{NH}_{4}, \mathrm{PO}_{4}, \mathrm{NO}_{2}+\mathrm{NO}_{3}\right)$. However, the relationship of the number of species to water quality variables was low, with $\mathrm{R}^{2}$ 's of 0.320 and 0.430 (Tables 4 and 7).

\section{Discussion}

From the results it is clear that both types of diatom-based indicators (diversity and aut-ecological) used were significantly influenced by water quality variables. From the three different diversity indices calculated, the number of species showed the strongest response to changes in water quality variables, although this relationship is fairly weak (Fig. 2). Of all the indicators tested in the study, the species diversity and the species evenness showed the weakest response to water quality variables (Tables 2 and 3).

From the $2^{\text {nd }}$ degree polynomial multiple regressions, it can be seen that the highest species diversity and evenness as well as number of species occur in moderately impacted water as suggested by Archibald (1971) and Van Dam (1982). A high degree of dominance may therefore be expected at both clean water and polluted water sites. It would seem logical to conclude that moderately impacted water can harbor species that can be dominant in either good or polluted water, as observed by Van Dam (1982).

Due to the fact that the species evenness does not exhibit a strong linear association with water quality, it would be logical to conclude that, in the case of diatoms, a high level of dominance in the population (as would be represented by a low evenness index in this study) cannot be equated to polluted or less favorable conditions. It would be more consistent with the data to expect that diatoms have well defined niches and that taxa best suited to water quality conditions at a specific point in time will become dominant. This is borne out by Cholnoky (1960) who stated that: “...it should be pointed out that changes in one or other of the factors which have been discussed here $[\mathrm{pH}$, salinity and nutrient concentrations] need not necessarily bring about the death of one or other of the algal species so long as the changes remain within the limits occurring in nature. On the contrary, these changes will inhibit the multiplication of some of the species originally present, and encourage that of others, so that primarily the association i.e. the percentage composition and not the flora as such, will be changed" (own italics).

This would also suggest that specific diatom taxa will be dominant in certain (and most) water quality conditions. Representatives of many species are always present in low numbers in the population and can become dominant when water quality is suitable.

The data are also consistent with postulations from Kelly (1998) who discussed the concept that diatoms are 'subcos-

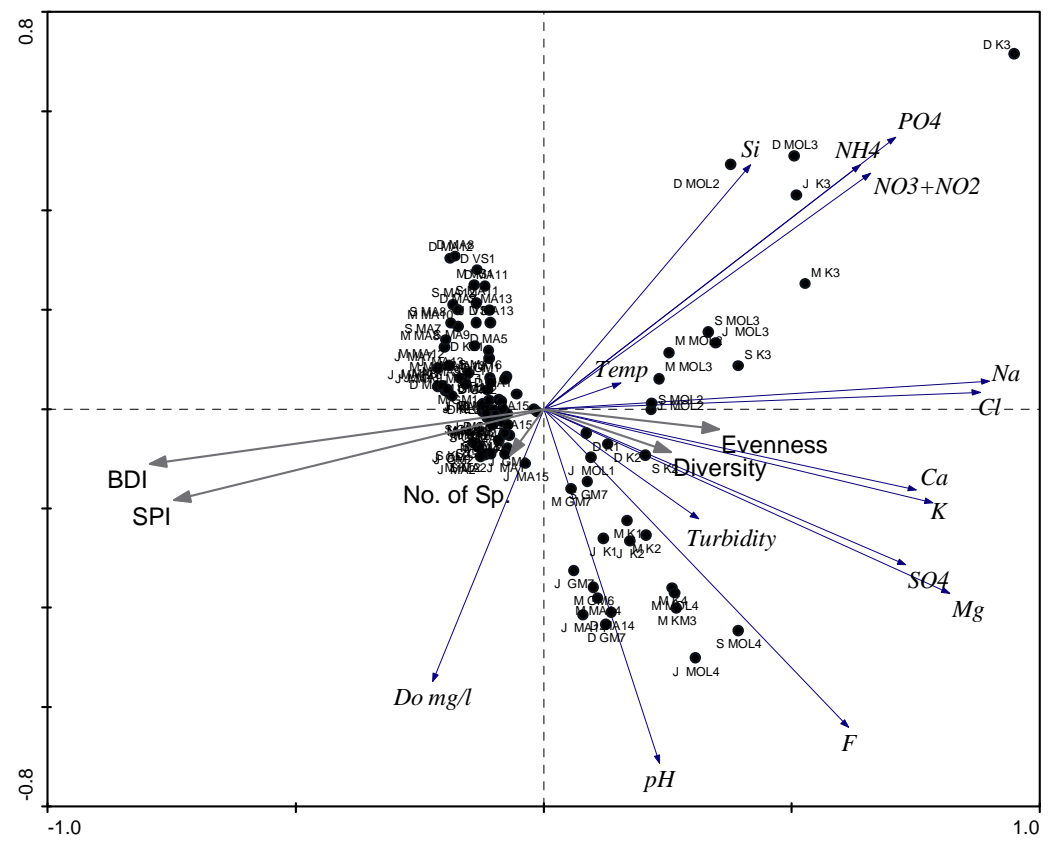

Figure 2

Principle component analysis (PCA) indicating chemical variables and diatom-based indices as vectors and sites as dots (site names are denoted by a letter denoting the month of sampling, followed by the site name as indicated in Fig. 1) 


\begin{tabular}{|l|c|c|c|c|c|c|}
\hline \multicolumn{7}{|c|}{ TABLE 10 } \\
$\begin{array}{c}\text { Results for PCA performed for sites in the Marico and Molopo Rivers } \\
\text { (Biological and habitat indices were used as supplementary data in the ordination) }\end{array}$ \\
\hline Axes & $\mathbf{1}$ & $\mathbf{2}$ & $\mathbf{3}$ & $\mathbf{4}$ & Total variance \\
\hline Species-environment correlations & 0.803 & 0.378 & 0.331 & 0.143 & \\
\hline Cumulative percentage variance: & & & & & \\
of species data & 40.6 & 57.8 & 70.5 & 78.8 & \\
of species-environment relation & 81.1 & 88.7 & 93 & 93.6 & \\
\hline Sum of all canonical eigenvalues & & & & & 0.323 \\
\hline
\end{tabular}

mopolitan', i.e. they occur anywhere in the world if certain environmental conditions are fulfilled. This concept suggests that geographical location is not the determining factor in the distribution of diatom species and the composition of communities, but it is rather the specific environmental variables at a specific site that determine this distribution. Finlay (2005) also states that it is now clear that distribution patterns of protists are quite different from those of macroscopic organisms - e.g. the recent discovery of the ubiquity-biogeography transition, where organisms smaller than about $1 \mathrm{~mm}$ occur worldwide wherever their required habitats are realised. However, some diatoms may be more susceptible to desiccation etc. and thus may not be so easily distributed. This would appear to be the case when (possibly) endemic diatoms such as Achnanthes standerii Cholnoky are found en masse in certain rivers and streams around South Africa but have never been reported from outside our borders. Whether diatoms such as these are in fact true endemics or if their distribution is simply governed by the factors such as local geology and climate, which may not be found elsewhere, remains a topic for further investigation.

In comparison to the diversity indices, the BDI and SPI as representatives of aut-ecological indices displayed a significantly better relationship with measured water quality variables as shown by the multiple regression results. It is also important to note that the relationship of the BDI and SPI with water quality did not increase significantly when the quadratic functions were added. The implication of this would be that the aut-ecological indices may be applied in a linear fashion in contrast to diversity indices.

The abovementioned results indicate that aut-ecological indices based on diatoms are more useful in biomonitoring programs of rivers and streams than diversity indices; a point strongly supported by the high $\mathrm{R}^{2}$ values of the linear multiple regressions for SPI and BDI in Table 8 and 9.

\section{Conclusions}

The current study and the results presented in the different sections of the current study warrant the following conclusions:

- Diversity measures based on the abundance of diatoms appear to show a relationship to water quality variables although that relationship is not linear

- The results from the linear and $2^{\text {nd }}$ degree polynomial regressions show that diatom species diversity (especially as reflected by the Shannon Species Diversity Index used in this study) tends to be higher in moderately impacted water

- Due to the highly significant relationship of aut-ecological diatom indices with water quality, these indices are deemed more relevant and reliable for use in rivers and streams to inform decision making in integrated water resource management.

\section{References}

ARCHIBALD REM (1971) Diversity in some South African diatom associations and its relation to water quality. Water Res. 6 12291238.

ARES JO, VILLA A and GAYOSOT AM (1983) Chemical and biological indicators of fluoride input in the marine environment near an industrial source (Argentina). Arch. Environ. Contam. Toxicol. 12 (5) 589-602.

CEMAGREF (1982) Etude Des Méthodes Biologiques Quantitatives D’appréciation De La Qualité Des Eaux. Rapport Division Qualité des Eaux Lyon. Agence financiè de Bassin Rhone-Méditerarée. Corse, Pierre-Bénite. 28 pp.

COSTE M and AYPHASSORHO H (1991) Étude De La Qualité Des Eaux Du Bassin Artois-Picardie A L'aide Des Communautés De Diatomées Benthiques (Application Des Indices Diatomiques). Rapport Cemagref. Bordeaux - Agence de l'Eau Artois-Picardie, Douai.

CHOLNOKY BJ (1960) The Relationship Between Algae and the Chemistry of Natural Waters. CSA (Counseil Scientifique Pour l'Afrique Au Sud Du Sahara). Specialist meeting on water treatment, Commission for Technical Co-operation in Africa South of the Sahara, Publication No. 64. 215-225.

CUNNINGHAM L, STARK JS, SNAPE I, MCMINN A and RIDDLE MJ (2003) Effects of metal and petroleum hydrocarbon contamination on benthic diatom communities near Casey station, Antarctica: an experimental approach. J. Phycol. 39 490-503.

DAVIES B and DAY J (1998) Vanishing Waters. University of Cape Town Press. University of Cape Town. Rondebosch, South Africa. $487 \mathrm{pp}$.

DE LA REY PA, TAYLOR JC, LAAS A, VAN RENSBURG L and VOSLOO A (2004) Determining the possible application value of diatoms as indicators of general water quality: A comparison with SASS 5. Water SA 30 (3) 325-332.

DE LA REY PA, ROUX H, VAN RENSBURG L and VOSLOO A (2008) On the use of diatom-based biological monitoring. Part 2: A comparison of the response of SASS 5 and diatom indices to water quality and habitat variation. Water SA 34 (1) 61-70.

DELL'UOMO A (1996) Assessment of water quality of an Apennine river as a pilot study. In: Whitton, BA and E Rott (eds.) Use of Algae for Monitoring Rivers II. Institut für Botanik. Universität Innsbruck. 65-73.

DESCY JP (1979) A new approach to water quality estimation using diatoms. Nova Hedwigia 64 305-323.

ELTON CS (1958) The Ecology of Invasions by Animals and Plants. Methuen, London. 209 pp.

FINLAY BJ (2005) Are microbial eukaryotes the most speciose group on the planet? Phycol. 44 (4) 32-33.

GÓMEZ N (1999) Epipelic diatoms from the Matanza-Riachuelo River (Argentina), a highly polluted basin from the pampean plain: Biotic indices and multivariate analysis. Aquat. Ecosyst. Health Manage. 2 301-309.

GRACIA-CRIADO F, TOME A, VEGA FJ and ANTOLIN C (1999) Performance of some diversity and biotic indices in rivers affected by coal mining in northwestern Spain. Hydrobiol. 394 209-217.

HAIR JF JR, ANDERSON RE, TATHAM RE and BLACK W (1998) Multivariate Data Analysis. Prentice-Hall, New Jersey. 730 pp.

HALL RI, and SMOL JP (1992) A weighted-averaging regression and calibration model for inferring total phosphorus concentration from 
diatoms in British Columbia (Canada) lakes. Freshwater Biol. 27 417-434.

HODGKISS IJ and LAW CY (1985) Relating diatom community structure and stream water quality using species diversity indices. Water Pollut.Control 134-139.

JOY CM and BALAKRISHNAN KP (1990) Effect of fluoride on axenic cultures of diatoms Journal Water. Air \& Soil Pollut. 49 (3-4) 241249.

KELLY MG (1998) Use of community-based indices to monitor eutrophication in European rivers. Environ. Conserv. 25 (1) 22-29.

KRAMMER K and LANGE-BERTALOT H (1986-1991) Bacillariophyceae. Süßwasserflora von Mitteleuropa 2 (1-4). Spektrum Akademischer Verlag, Heidelberg. Berlin.

LECLERQ L and MAQUET B (1987) Deux Nouveaux Indices Chimique Et Diatomique De Qualité D’eau Courante. Application Au Samson Et A Ses Affluents (Bassin De La Meuse Belge). Comparaison Avec D’autres Indices Chimiques, Biocénotiques Et Diatomiques. Institut Royal des Sciences Naturelles de Belgique, document de travail 28.

LECOINTE C, COSTE M and PRYGIEL J (1993) "Omnidia”: Software for taxonomy, calculation of diatom indices and inventories management. Hydrobiol. 269/270 509-513.

LENOIR A and COSTE M (1996) Development of a practical diatom index of overall water quality applicable to the French National Water Board network. In: Whitton BA and Rott E (eds.) Use of Algae for Monitoring Rivers II. Institut für Botanik. Universität Innsbruck, Austria. 29-43.

LEWIN JC (1962) Silicification. In: RA Lewin [ed.] Physiology and Biochemistrof Algae. Academic Press, London. 445-456.

LEWINS WA and JOANES DN (1984) Bayesian estimation of the number of species. Biometrics 40 323-328.

MAY RM (1976) Patterns in Multi-Species Communities. In: May RM (ed.) Theoretical Ecology: Principles and Applications. Blackwell, Oxford. 142-162.

McCORMAK PV and CAIRNS JR J (1994) Algae as indicators of environmental change. J. Appl. Phycol. 6 509-526.

NETER J, WASSERMAN W and KUTNER MH (1985) Applied Linear Statistical Models ( $2^{\text {nd }}$ edn.). Illinois: Richard D Irwin, INC. 1989 pp.

PIMM SL (1984) The complexity and stability of ecosystems. Nature 307 321-326.

PRYGIEL J, LEVEQUE L and ISERENTANT R (1996) Un nouvel indice diatomique pratique pour l'évaluation de la qualité des eaux en réseau de surveillance. Revue des Sciences de l'Eau 1 97-113.

REAVIE ED, HALL RI, and SMOL JP (1995) An expanded weightedaveraging model for inferring past total phosphorus concentrations from diatom assemblages in eutrophic British Columbia (Canada) lakes. J. Paleolimnol. 14 49-67.

REID MA, TIBBY JC, PENNY D and GELL PA (1995) The use of diatoms to assess past and present water quality. Aust J. Ecol. 20 57-64.

RIVER HEALTH PROGRAMME (2005) State-of-Rivers Report: Monitoring and Managing the Ecological State of Rivers in the Crocodile (West) Marico Water Management Area. Department of Environmental Affairs and Tourism, Pretoria, South Africa. 29 pp.

ROTT E (1991) Methodological aspects and perspectives in the use of periphyton for monitoring and protecting rivers. In: Whitton BA, Rott E and Friedrich G (eds.) Use of Algae for Monitoring Rivers. Institut fur Botanik, Univ. Innsbruck. 9-16.

SABATER S (2000) Diatom communities as indicators of environmental stress in the Guadiamar River; S-W. Spain, following a major mine tailings spill. J. Appl. Phycol. 12 113-124.

SEBER GAF (1986) A review of estimating animal abundance. Biometrics 42 267-292.

SHANNON CE and WEAVER W (1949) The Mathematical Theory of Communication. University of Illinois Press, Urbana. 117 pp.

SLADECEK V (1986) Diatoms as indicators of organic pollution. Acta Hydrochim. et Hydrobiol. 14 555-566.

STOERMER EF and SMOL JP (1999) The Diatoms: Application for the Environmental and Earth Sciences. University Press, Cambridge. 467 pp.

TAYLOR JC, DE LA REY PA and VAN RENSBURG L (2005) Recommendations for the collection, preparation and enumeration of diatoms from riverine habitats for water quality monitoring in South Africa. S. Afr. J. Aquat. Sci. 30 (1) 65-75.

TAYLOR JC, JANSE VAN VUUREN MS and PIETERSE AJH (2007) The application and testing of diatom-based indices in the Vaal and Wilge Rivers, South Africa. Water SA 33 (1) 51-60.

VAN DAM H (1982) On the use of measures of structure and diversity in applied diatom ecology. Nova hewigia 73 97-115.

WALMSLEY RD (2000) Perspectives on Eutrophication of Surface Waters: Policy/Research Needs in South Africa. WRC Report No KV129/00. Water Research Commission. Pretoria, South Africa.

ZEEB BA, CHRISTIE CE, SMOL JP, FINDLAY DL, KLING H and BIRKS HJB (1994) Responses of diatom and chrysophyte assemblages in Lake 227 sediments to experimental eutrophication. Can. J. Fish. Aquat. Sci. 51 2300-2311.

ZELINKA M and MARVAN P (1961) Zur Präzisierung der biologischen Klassifikation der Reinheit fliessender Gewässer. Arch. Hydrobiol. 57 389-407. 